\title{
Korkeakoulujen täydennyskoulutus - tilanne ja kehitysnäkymiä
}

Väisänen, Riitta 1988. Korkeakoulujen täydennyskoulutus - tilanne ja kehitysnäkymiä. Aikuiskasvatus $8,2,13-18$.

Korkeakoulujen täydennyskoulutus on viime vuosina ollut korkeakoulujen voimakkaimmin laajeneva toiminta-alue. Kaikki maamme korkeakoulut järjestävät täydennyskoulutusta. Toiminta on monimuotoista ja monipuolista, eri korkeakoulujen toiminnalle asettamat tavoitteet ja painopisteet vaihtelevat. Joissain korkeakouluissa oman korkeakoulun erityisosaamisen välittäminen valtakunnallisena täydennyskoulutuksena nähdään keskeisimpänä, muutamissa muissa korkeakouluissa alueelliset täydennyskoulutustarpeet nousevat etualalle. Useimmissa tapauksissa nämä tavoitteet yhdistyvät.

Korkeakoulujen täydennyskoulutus muodostuu ammatillisista täydennyskoulutuskursseista ja -ohjelmista, työllisyyskoulutuksesta sekä avoimesta korkeakouluopetuksesta. Myös korkeakouluissa laajeneva, lähinnä aluepoliitttisin perustein järjestettävä yrityspalvelutoiminta sisältää koulutuspalvelujen tarjoamista. Täydennyskoulutuskeskukset korkeakoulupaikkakunnilla ja niiden sivutoimipisteet useilla muilla paikkakunnilla muodostavat koko maan kattavan korkeakoulutasoisen täydennyskoulutuksen verkoston.

\section{Täydennyskoulutuksen tavoitteet}

Korkeakoululaitoksen kehittämislain (1052/ 86) yleisperusteluissa todetaan, että korkeakoulut järjestävät täydennyskoulutusta korkeakoulututkinnon jo suorittaneille ja avointa korkeakouluopetusta aikuisväestölle. Täydennyskoulutusta on lisäksi käsitelty useammassakin valtioneuvoston vahvistamassa korkeakoululaitoksen kehittämissuunnitelmassa ja muissa opetusministeriön suunnitteluasiakirjoissa. Enää ei ole tarpeen keskustella siitä, kuuluuko täydennyskoulutus korkeakoulujen tehtäviin se on tullut sinne jäädäkseen.

Täydennyskoulutuksen määrälliset ja laadulliset tavoitteet määrittelee kukin korkeakoulu itse. Korkeakoulun tulee arvioida edustamiensa koulutusalojen ja toiminta-alueensa koulutustarpeita ja siltä pohjalta suunnitella itselleen soveltuva, korkeakoulujen muuta toimintaa tukeva täydennyskoulutustarjonta. Opetusministeriön tavoitteena on ollut lähinnä puitteiden luominen täydennyskoulutustoiminnalle, esimerkiksi rahoitusjärjestelyn mahdollistaminen sekä joidenkin erityisvoimavarojen osoittaminen. Opetusministeriön taholta on luonnollisesti korostettu täydennyskoulutuksen laatua.

Täydennyskoulutustoiminnassa tulee hyödyntää korkeakoulun erityisosaamista, koulutuksen on oltava korkeakoulutasoista. Käytän- nössä tämä tarkoittaa mm. sitä, että koulutuksella on kiinteä yhteys korkeakoulun muuhun toimintaan, opetukseen ja tutkimukseen ja että korkeakoulu ei lähde järjestämään täydennyskoulutusta aloille ja kohderyhmille, joille muut koulutuksen järjestäjät jo tarjoavat riittäviä koulutuspalveluja. Edelleen yhteistoiminnan ja työnjaon kehittäminen muiden koulutuksen järjestäjien kanssa on tarpeen sekä alueellisesti että valtakunnallisesti. Korkeakoulujen täydennyskoulutuskeskusten välinen yhteistyö nähdään myös tärkeänä.

\section{Täydennyskoulutuksen laajuus}

Korkeakoulujen täydennyskoulutuksen järjestämisestä huolehtivat erillislaitoksina toimivat täydennyskoulutuskeskukset, jotka on pääosin perustettu 1980-luvulla. Edelläkävijä oli Tampereen yliopiston täydennyskoulutuskeskus, joka perustettiin vuonna 1970. Toiminnan laajeneminen on tapahtunut 1980-luvulla. Syitä on useita: täydennyskoulutuskysynnän kasvu työtehtävien laadun muuttuessa, tarve asiantuntija-apuun elinkeinotoiminnan kehittämisessä, työllisyyskoulutusmäärärahojen suuntaaminen myös korkeakoulujen käyttöön, korkeakoulujen lisääntynyt kiinnostus kontaktien kehittämi- 
seen ympäristön kanssa. Ilmeistä myös on, että paineet täydennyskoulutuksen edelleen kehittämiseen ovat voimakkaita.

Täydennyskoulutuksen laajuustietojen antamista haittaavat puutteelliset tilastot ja tiedostot, joiden kehittäminen on vasta saatu käyntiin. Seuraavasta taulukosta käyvät ilmi osallistujamäärät vuonna 1986.

\section{Osanottajat vuonna 1986}

ammatilliset kurssit ja ohjelmat työllisyyskoulutus avoin korkeakouluopetus

Täydennyskoulutuskeskuksissa työskenteli vuoden 1987 lopussa 526 henkeä täydennyskoulutuksen suunnittelu- ja toteutustehtävissä. Opettajina käytetään korkeakoulujen omia opettajia ja osittain ulkopuolisia asiantuntijoita. Ulkopuolisten asiantuntijoiden käyttö vaihtelee korkeakouluittain ja kulloinkin kyseessä olevan koulutustapahtuman osalta.

Opetusministeriö tiedusteli korkeakouluilta helmikuussa 1988 täydennyskoulutuksen volyymia vuonna 1987 kustannuksilla mitattuna. Alustavien, tarkistamattomien tietojen mukaan täydennyskoulutustoiminnan "liikevaihto" kaikissa korkeakouluissa oli yhteensä runsaat 130 miljoonaa markkaa.

\section{Ammatillinen täydennyskoulutus}

Korkeakoulujen täydennyskoulutuksen ydinalueen muodostavat edelleen ammatilliset täydennyskoulutuskurssit ja -ohjelmat. Koulutusta tarjotaan eri kohderyhmille yhden päivän tilaisuuksista aina kahden kolmen vuoden ajan jatkuviin ohjelmiin saakka. Kohderyhmiä on runsaasti: opettajat, sosiaali- ja terveydenhuollon työntekijät, yritysjohtajat jne. Kurssien keskipituus vuonna 1986 oli 6 kurssipäivää tai 39 opetustuntia. Tällöin $79 \%$ kursseista oli $1-5$ päivän kestoisia ja $21 \%$ kesti yli 5 kurssipäivää. Korkeakoulujen tulisi tulevaisuudessa keskittyä pitempikestoisten täydennyskoulutusohjelmien tarjoamiseen.

Suurin ongelma ammatillisen täydennyskoulutuksen järjestämisessä oli pitkään rahoitus. Vuoden 1986 valtion tulo- ja menoarviossa muutettiin toiminta maksulliseksi palvelutoiminnaksi, jota tuetaan valtion budjettiin sisältyvin erityismäärärahoin. Ratkaisu on osoittautunut toimivaksi. Koulutuksen kustannuksiin osallistuvat näin ollen pääsääntöisesti koulu- tettavien työnantajat, joissain tapauksissa koulutettavat itse ja koulutuspoliittisista syistä myös valtio. Unohtaa ei toki sovi, että useat kunnat ovat erittäin voimakkaasti tukeneet täydennyskoulutustoiminnan aloittamista ja ylläpitoa omilla paikkakunnillaan.

Suurimmaksi ongelmaksi on koettu valtion tukkirahoituksen riittämättömyys, vuonna 1986 5,5 Mmk, vuonna 1987 10,5 Mmk ja vuonna 198811 Mmk tiedekorkeakouluille. Tukea tarvitaan lähes kaikilla koulutusaloilla, erityisesti pitkäkestoisten koulutusohjelmien suunnitteluun ja kehittämiseen. Täydennyskoulutuksen maksullisuus on luonnollisesti aiheuttanut pohdintaa siitä, missä määrin täydennyskoulutuskeskukset ovat muuttumassa liiketaloudellisin perustein toimiviksi yksiköiksi, jotka järjestävät vain sellaista koulutusta, jolle löytyy ulkopuolinen maksaja. Ja keskittyykö tällöin korkeakoulujen täydennyskoulutus ainoastaan niille aloille, joilla on maksukykyä muiden alojen jäädessä vaille tarpeellista koulutustarjontaa. Vai arvioivatko korkeakoulut täydennyskoulutuksensa kehittämistä myös tulevaisuudessa koulutuspoliittisista lähtökohdista. Valtion tukirahoituksen suuruus vaikuttaa osaltaan strategian valintaan. Yhden toimintamallin tarjoaa ns. sopimuskoulutus kuntien tai yritysten kanssa.

Suuren haasteen täydennyskoulutustoiminnalle asettaa vaatimus koulutuksen jatkuvasta uudistamisesta, innovatiivisyyden säilyttämisestä ja kyvystä joustavasti vastata muuttuviin koulutustarpeisiin.

\section{Työllisyyskoulutus}

Korkeakoulut ovat järjestäneet työllisyyskoulutusta 1970-luvun lopusta lukien. Toiminta laajeni huomattavasti vuosina 1981-83 ja on sittemmin pysynyt volyymiltään samana eli noin 10000 oppilaskuukautena (noin 1300 aloituspaikkaa) vuodessa.

Työllisyyskoulutusvaroin järjestetään koulutusta erityiskoulutetuille työttömille tai työttömyysuhan alaisille henkilöille sekä pienyrittäjille ja maaseudun sivuelinkeinojen kehittämiseksi. Erityisesti jälkimmäinen eli yrittäjäkoulutus on ollut jatkuvan keskustelun ja myös kritiikin kohteena.

Vuosikymmenen alkuvuosina työllisyyskoulutus muodosti huomattavan osan korkeakoulujen täydennyskoulutuksesta sekä koulutuksen määrillä että markoilla mitattuna. Toimintaan oli käytettävissä väljemmin määrärahoja kuin korkeakoulujen toimintaan muutoin, mikä aiheutti arvostelua, mutta mikä toisaalta mahdollisti koulutuksen perusteellisen suun- 
nittelun ja erilaisten koulutusmallien kehittämisen. Useissa tapauksissa täydennyskoulutuskeskukset ovat pystyneet siirtämään työllisyyskoulutuksena kehittämiään koulutusideoita maksullisina toteutettaviksi kursseiksi tai sopimuskoulutukseksi. Myös työllisyyskoulutukseen liittyvästä harjoittelusta saadut kokemukset ovat hyödyttäneet perusopetukseen sisältyvän harjoittelun kehittämistä.

Yrittäjäkoulutuksen avulla korkeakoulujen täydennyskoulutuskeskukset ovat pystyneet luomaan kontakteja ympäristöönsä ja hyödyntämään näitä muussakin toiminnassaan. Yrittäjäkoulutusta on joissain tapauksissa liitetty laajempiin alueellisiin tai toimialakohtaisiin kehittämishankkeisiin. Voidaan toki oikeutetusti sanoa, että yrittäjäkoulutuksessa korkeakoulut ovat järjestäneet koulutusta, joka pääosin olisi sopinut paremmin esim. ammatillisten kurssikeskusten tai kauppaoppilaitosten järjestettäväksi ja että yrittäjäkoulutus on usein ollut hyvin irrallaan korkeakoulun muusta toiminnasta. Lisäksi on havaittavissa, että yrittäjäkoulutuksessa on viime vuosina tyydytty vanhojen koulutusmallien toistamiseen, eikä uusia ideoita juurikaan ole syntynyt. Toisaalta työvoimaministeriön teettämien tutkimusten mukaan korkeakoulujen järjestämän työllisyyskoulutuksen tulokset ovat olleet keskimäärin hyviä koulutetut ovat työllistyneet ja yritysten työpaikkoja on pystytty säilyttämään ja lisäämään. Kuuluuko työllisyyskoulutus korkeakoulun tehtäviin on viimekädessä korkeakoulun itsensä päätettävissä - 16 korkeakoulua on järjestämässä tätä koulutusta.

\section{Avoin korkeakouluopetus}

Avoimella korkeakouluopetuksella tarkoitetaan korkeakoulujen opetussuunnitelmiensa mukaisesti järjestämää, aikuisväestölle tarkoitettua opetusta, joka on riippumatonta osallistujien pohjakoulutuksesta ja opintojen tavoitteista. Korkeakoulu voi järjestää avointa korkeakouluopetusta joko itse tai yhteistyössä aikuisoppilaitoksen tai muun koulutusorganisaation kanssa. Tämä määritelmä sisältyy opetusministeriön joulukuussa 1986 antamiin avoimen korkeakouluopetuksen järjestämistä koskeviin ohjeisiin. Mainitussa päätöksessä edellytetään myös, että korkeakoulut itse saattavat tavoitteensa avoimen korkeakouluopetuksen järjestämiselle ja varaavat tarvittavat voimavarat. Avoimesta korkeakouluopetuksesta tulee olla myös mahdollisuus siirtyä suorittamaan perustutkintoa 60 opintoviikon suoritusten jälkeen. Ohjeita annetaan lisäksi tiedotuksen ja opinto- ohjauksen järjestämisestä, yhteistyöstä ja siitä solmittavista sopimuksista käytettävissä olevista voimavaroista, tilastoinnista ja todistuksista.

Vuonna 1986 avoimeen korkeakouluopetukseen osallistui yhteensä noin 21500 'henkeä, vuoden 1987 osanottajamäärä on alustavien tietojen mukaan noin 26500 henkeä. Ylivoimaisesti suosituimpia olivat kasvatustieteelliset aineet, lähes $40 \%$ osanottajista, myös yhteiskuntatieteellisisllä, psykologian ja humanistisilla aloilla järjestetään melko systemaattista avoimen tarjontaa. Sen sijaan luonnontieteissä tarjonta on sangen vähäistä, kauppatieteessä lähes ja tekniikan alalla täysin olematonta. Järjestetystä opetuksesta pääosa on kuitenkin alempia aineopintoja, ja ylempien aineopintojen tarjonta on ollut satunnaista.

Avoin korkeakouluopetus muodostuu kahdenlaisesta opetustarjonnasta. Kymmenen korkeakoulua järjestää luento-opetusta omilla toiminta-alueillaan joko itse tai yhdessä kansalais- ja työväenopistojen tai kansanopistojen kanssa. Kesäyliopistot puolestaan huolehtivat kesäaikaisesta avoimen korkeakouluopetuksen järjestämisestä useilla paikkakunnilla. Talviaikainen opetus järjestetään useimmiten iltaisin tai viikonloppuisin, kyseessä on kuitenkin perinteisen lähiopetuksen tarjoaminen aikuisille. Toisena avoimen korkeakouluopetuksen muotona muutamat korkeakoulut ovat kehittäneet monimuoto-opetusta. Turun ja Helsingin yliopistoilla on tästä eniten kokemuksia, mutta myös muualla on toteutettu $\mathrm{mm}$. radio- ja televisiokursseja.

Avoimen korkeakouluopetuksen tarjonnasta toteutetaan vuoden 1986 tietojen mukaan lähes $80 \%$ yhteistyössä aikuisoppilaitosten kanssa. Tavoitteena ei maassamme missään vaiheessa ole ollut erillisen Avoimen Yliopiston perustaminen. Tähän ovat vaikuttaneet sekä taloudelliset että koulutuspoliittiset syyt. Erillisen oppilaitoksen perustaminen tulee kalliiksi, korkeakouluopetusta ei ole haluttu erottaa tiedeyhteisöstä ja maamme korkeakouluverkko sekä kansalais- ja työväenopistojen, kansanopistojen ja kesäyliopistojen verkosto luo mahdollisuudet alueellisesti kattavan tarjonnan aikaansaamiseen. Yhteistyössä ei myöskään ole ilmennyt mitään periaatteellisia ongelmia ja halukkuutta yhteistyön kehittämiseen on kaikilla osapuolilla. Myös kansainväliset kokemukset osoittavat toimintalinjan valinnan perustelluksi.

Avoimen korkeakouluopetuksen keskeisimpiä kysymyksiä on sen suhde korkeakoulujen perusopetukseen. Korkeakoulujen johdon ja laitosten opettajakunnan asenteista ja halukkuudesta riippuu mahdollisuus kehittää avointa korkeakouluopetusta osana laitoksen perusopetustarjontaa. Avoin korkeakouluopetus edellyttää uusien opetusmuotojen ja opiskelija- 
keskeisten oppimismenetelmien kehittämistä. Tämä kehittäminen voitaisiin tehdä yhteisesti avoimen korkeakouluopetuksen ja perusopetuksen osalta. Se edellyttää heterogeenisen opiskelijajoukon tarpeiden nykyistä suurempaa huomioonottamista, laitoksen opetusresurssien käytön uudelleen arviointia ja kohdentamista sekä uusien opetusmuotojen ja menetelmien kehittämistä ja kokeilua. Turun yilopiston päätoimisten tuntiopettajien osoittaminen niille laitoksille, joiden avoimen opetuksen tarjonta on riittävän laajaa ja pysyvää, on yksi esimerkki mahdollisista uudelleenjärjestelyistä.

Toinen keskeinen kysymys on monimuotoopetuksen kehittäminen. Avoimen korkeakouluopetuksen tekeminen todella ajasta ja paikasta riippumattomaksi edellyttää monimuotoopetuksen ja -opiskelun kehittämistä. Tarkoituksena on, että eri korkeakoulut osallistuvat tähän työhön. Monimuoto-opetuksen kehittämiseen liittyy monia ongelmia. Miten turvataan keskeisimpien aineiden valtakunnallinen tarjonta? Luontevaa olisi, että samat etäopetusmateriaalit olisivat kaikkien korkeakoulujen käytössä, jotka sitten alueellisesti toteuttaisivat opetuksen. Jo toisistaan poikkeavat tutkintovaatimukset asettanevat tälle esteitä. Uuden teknologian luomien mahdollisuuksien hyväksikäyttö opetuksessa tulisi mahdollistaa, mutta se on kallista. Löytyykö tähän riittävästi varoja ja miten koordinoidaan pienen maan rajalliset resurssit kaikkien tarvitsijoiden hyödyksi.

Kolmantena ongelma-alueena voisi vielä todeta avoimen korkeakouluopetuksen resurssoinnin. Eduskunta päätti vuoden 1986 tulo- ja menoarvion hyväksymisen yhteydessä, että avioin korkeakouluopetus järjestetään muilla kuin maksullisen palvelutoiminnan määrärahoilla. Tämä tarkoittaa, että korkeakoulujen tulee osoittaa resurssit avoimen korkeakouluopetuksen kehittämiseen omista määrärahoistaan ja samalla opetus on opiskelijoille maksutonta. Avoimeen korkeakouluopetukseen on osoitettu erillisresursseja vain vähäisessä määrin, eivätkä korkeakoulut toistaiseksi ole pitäneet avoimen korkeakouluopetuksen järjestämistä erityisen keskeisenä toiminta-alueenaan. Siten toiminnan resurssointi on ollut jatkuva keskustelun aihe. Osaltaan ongelmaa voisi helpottaa, jos opiskelijoilta voitaisiin periä opiskelumaksuja, joiden tuotto voitaisiin käyttää toiminnan kehittämiseen. Tällaisen järjestelyn toteuttaminen edellyttää lainsäädännöllisten ja käytännön ongelmien ratkaisemista. Opetusministeriössä aiotaan kuitenkin jälleen kerran ryhtyä selvittämään asiaa.

\section{Tulevaisuuden näköaloja}

Valtioneuvosto teki 5.3 .1987 periaatepäätöksen ammatillisen aikuiskoulutuksen rahoittamisen suunnitteluperiaatteista ja 24.3.1988 periaatepäätöksen ammatillisen aikuiskoulutuksen kehittämisestä. Molemmissa päätöksissä selkiytetään ammatillisen aikuiskoulutuksen rahoittammisjärjestelmää ja jälkimmäisessä otetaan kantaa koulutuksen järjestämisvàstuun jakautumiseen ja pyritään luomaan edellytyksiä sille, että aikuiskoulutusta järjestävät laitokset pystyvät nykyistä joustavammin ja tehokkaammin vastaamaan koulutuksen kysyntään ja siinä tapahtuviin muutoksiin. Taustalla on yhteiskunnallisesta rakennemuutoksesta ja työelämän nopeista muutoksista johtuvat uudet koulutusvaatimukset. Päätös koskee kaikkea ammatillista aikuiskoulutusta, siis myös korkeakoulujen järjestämää aikuiskoulutusta.

Eri tahojen vastuu ammatillisen aikuiskoulutuksen tarjonnasta

\begin{tabular}{|l|l|l|l|}
\hline $\begin{array}{l}\text { KOULU- } \\
\text { TUS- }\end{array}$ & $\begin{array}{l}\text { JÄRJESTÄ- } \\
\text { MIS- } \\
\text { VASTUU }\end{array}$ & $\begin{array}{l}\text { RAHOITUS- } \\
\text { VASTUU }\end{array}$ & $\begin{array}{l}\text { VASTUU } \\
\text { MAHDOLU- } \\
\text { SESTA } \\
\text { VALTION- } \\
\text { AVUSTA }\end{array}$ \\
\hline $\begin{array}{l}\text { OMA- } \\
\text { EHTOINEN } \\
\text { KOULUTUS }\end{array}$ & $\begin{array}{l}\text { Opetus- } \\
\text { ministeriö }\end{array}$ & $\begin{array}{l}\text { Valtio, koti- } \\
\text { kunta ja } \\
\text { opiskelija } \\
\text { itse }\end{array}$ & $\begin{array}{l}\text { Opetus- } \\
\text { ministeriö }\end{array}$ \\
\hline $\begin{array}{l}\text { HENKI- } \\
\text { KÖSTÖ- }\end{array}$ & $\begin{array}{l}\text { Opetusmi- } \\
\text { nisteriö ja } \\
\text { työnantaja }\end{array}$ & Työnantaja & $\begin{array}{l}\text { Asian- } \\
\text { omainen } \\
\text { ministeriö }\end{array}$ \\
\hline $\begin{array}{l}\text { TYÖLL- } \\
\text { SYYS- } \\
\text { KOULUTUS }\end{array}$ & $\begin{array}{l}\text { Opetus- } \\
\text { ministeriö }\end{array}$ & Valtio & $\begin{array}{l}\text { Työvoima- } \\
\text { ministeriö }\end{array}$ \\
\hline
\end{tabular}

Kuviosta selviää päätökseen sisältyvät kannanotot koulutuksen järjestämis- ja rahoitusvastuusta sekä mahdollisesta valtionavusta. Korkeakoulujen osalta lähinnä avoin korkeakouluopetus on omaehtoista koulutusta, ammatillinen täydennyskoulutus on pääosin henkilöstökoulutuksen luokkaan kuuluvaa ja korkeakoulut järjestävät myös työllisyyskoulutusta. Rajat eivät kuitenkaan kulje näiden eri koulutusmuotojen välissä, vaan avoin korkeakouluopetus voi joissain tapauksissa olla jopa henkilöstökoulutusta, eivätkä läheskään kaikki ammatilliset kurssit ja ohjelmat ole henkilöstökoulutusta.

Maaliskuussa 1988 tehty valtioneuvoston periaatepäätös sisältää seuraavat korkeakoulujen täydennyskoulutusta koskevat kohdat: 
- Korkeakoulujen avointa korkeakouluopetusta laajennetaan ja monipuolistetaan valtakunnallisena järjestelmänä siten, että opetusta on tarjolla maan kaikissa osissa ja eri koulutusaloilla ja että aikuisilla on todellinen mahdollisuus siirtyä suorittamaan korkeakoulututkintoa 60 opintoviikon suorittamisen jälkeen. Kesäyliopistoja kehitetään muun muassa osana aikuiskoulutusjärjestelmää. Niinikään käytetään hyväksi kansanopistojen sekä kansalaisja työväenopistojen tarjoamia mahdollisuuksia.

- Korkeakoulujen maksullisena palvelutoimintana järjestämää täydennyskoulutusta laajennetaan. Erityisesti kehitetään nykyistä pidempiä täydennyskoulutusohjelmia kunkin korkeakoulun omalla erityisalalla.

- Korkeakoulujen yrityspalvelutoimintaa laajennetaan ottaen huomioon myös aluepoliittiset perusteet. Niihin voidaan sisällyttää myös koulutuspalveluja.

- Työvoimahallinto tilaa kustannuksellaan työllisyyskoulutuksen korkeakouluilta ja muilta koulutuksen järjestäjiltä. Uudistus toteutetaan korkeakouluissa 1989.

- Korkeakoulujen työllisyyskoulutusta kehitetään nykyistä selvemmin kokeilu- ja kehittämistoimintana ja siihen sisällytetään myös tutkimuspalveluja.

- Aikuiskoulutukseen suuntautuvaa tutkimusta ja alan tieteellistä koulutusta tehostetaan aikuiskoulutusneuvoston vuonna 1987 valmisteleman aikuiskoulutuksen tutkimuspoliittisen ohjelman pohjalta. Tukea ohjataan nykyistä enemmän aikuiskoulutuksen perusteita ja kehittämistä koskevaan monitieteiseen ja erityisesti kasvatustieteelliseen tutkimukseen. Lisäksi pyritään yhdessä korkeakoulujen kanssa tehostammaan kasvatustieteiden tiedekuntien ja osastojen ammatilliseen aikuiskoulutukseen, korkeakoulujen järjestämään täydennyskoulutukseen ja avoimeen korkeakouluopetukseen suuntautuvaa tutkimustoimintaa.

- Aikuiskoulutuksen menetelmiä sekä erityisesti monimuoto-opetuksessa tarvittavia opiskelijakeskeisiä työtapoja ja oppimateriaaleja kehitetään. Etäopetusta tehostetaan.

Päätökseen sisältyy lisäksi kannanotot aikuisopiskelijoiden opintotuen kehittämisestä, tilastointijärjestelmän kehittämisestä, tieto- ja neuvontapalvelun luomisesta, aikuiskoulutusta järjestävien laitosten yhteistoiminnan tehostamisesta ja seurantaryhmän perustamisesta. Päätökseen liittyy laaja perustelumuistio, joka sisältää myös rahoitussuunnitelman vuodelle 1989. Rahoituksesta päätetään lopullisesti vuoden 1989 valtion tulo- ja menoarvion valmistelun yhteydessä.

Mitä päätös sitten merkitsee korkeakoulujen täydennyskoulutustoiminnalle? Lähinnä kysy- myksessä on nykyisen toiminnan perusteiden vahvistaminen ja toiminnan laajentaminen ja monipuolistaminen, koska korkeakoulujen täydennyskoulutustoimintaa on jo vuodesta 1986 toteutettu niiden rahoitusperiaatteiden mukaan, jotka päätöksessä esitetään. Avoimen korkeakouluopetuksen ja ammatillisen täydennyskoulutuksen kannalta perustelumuistion rahoitussuunnitelma tuo olennaisen parannuksen toimintaedellytyksiin. Monimuoto-opetuksen kehittäminen saadaan myös alkuun nykyistä huomattavasti merkittävämmässä laajuudessa.

Suurempi muutos on vuonna 1989 siirtyminen korkeakoulujen työllisyyskoulutuksessa järjestelmään, jossa työvoimaviranomaiset ostavat työllisyyskoulutuspalvelut korkeakouluilta. Tarkoituksena on korostaa koulutuksen merkitystä työvoimapoliittisena toimenpiteenä, lisätä koulutuksen joustavuutta ja tehokkuutta sekä paikallista asiantuntemusta ja vähentää keskushallinnon byrokratiaa. Käytännössä työvoimapiirit tulevat ensi vuoden alusta lähtien ostamaan koulutuspalvelut. Akateemisten työttömien osalta tulisi samalla saada toteuttaa mahdollisuus työttömille. Merkittävä on myös periaatepäätöksen kanta siitä, että korkeakoulujen työllisyyskoulutusta kehitetään kokeilu- ja kehittämistoimintana ja siihen sisällytetään tutkimuspalveluja. Tämän toteuttaminen asettaa suuret vaatimukset niin työvoimahallinnolle kuin korkeakoulujenkin suunnittelijoille.

\section{Täydennyskoulutuksen kehittämisorganisaatio}

Opetusministeriö asettı jo vuonna 1983 korkeakoulujen täydennyskoulutuksen kehittämisprojektin. Projektilla on jatkoryhmä, jonka tehtäväksianto ja kokoonpano uusittiin tämän vuoden alussa. Johtoryhmä asetti jaoston kehittämään erityisesti avointa korkeakouluopetusta. Johtoryhmässä ja jaostossa on edustajia eri korkeakouluista, opetusministeriöstä, Suomen kesäyliopistot ry:stä ja Oy Yleisradio Ab:stä. Johtoryhmän määräaika on vuoden 1989 loppuun. Kuluvan vuoden tehtäviä ovat monimuoto-opetuksen kehittäminen, yhteistyökysymykset, tutkimustoiminnan tehostaminen, täydennyskoulutuksen rahoitusjärjestelmän toimivuuden arviointi, voimavarojen tarpeen arviointi, avoimen korkeakouluopetuksen maksukysymys sekä kansainvälisen kehityksen seuraaminen.

Opetusministeriön keväällä 1987 asettama Kesäyliopistotoimikunta on saanut työnsä päätökseen. Mietintö luovutettiin toukokuun 


\section{( sivulta 17)}

alussa. Mietintöön sisältyy laaja katsaus kesäyliopistojen toimintaan ja tulevaisuuden kehittä-misnäkymiin sekä ehdotus valtioneuvoston ke-säyliopistojen valtionavusta antaman päätök-sen uusimiseksi että esitys kesäyliopistojen valtionavusta vuodelle 1990. Toimikunnan eh-dotukset esitetään toteutettavaksi vuonna 1990.

\section{Lopuksi}

Olen edellä pyrkinyt antamaan yleiskuvan kor-keakoulujen täydennyskoulutuksen tämänhet- kisestä tilanteesta ja ongelmista opetusministeriöstä nähtynä. Lopuksi haluaisin korostaa kahta asiaa: aikuiskoulutukseen suuntautuvan tutkimuksen tärkeyttä ja kansainvälisen kehityksen seuraamista ja muualla saatujen kokemusten soveltamista Suomen oloihin. Kuten valtioneuvoston periaatepäätöksessäkin todetaan, on tavoitteena aikuiskoulutuksen tutkimuksen tehostaminen korkeakouluissa. Tässä työssä tarvitaan nyt tutkijoiden aktiivisuutta, esityksiä tutkimus- ja kokeiluprojekteiksi ja toimenpiteitä tieteellisen jatkokoulutuksen tehostamiseksi. 
branches in many other localities form a universitylevel further education network that covers the entire country.

Riitta Väisänen. 1988. Further Education in the Universities - Present Situation and Future Prospects.

During the past few years further education has been the most rapidly expanding area within the universities in Finland. All the universities in the country offer rich and varied programs in further education. The specific goals and areas of emphasis of this type of education vary from university to university. Some universities choose to stress their own fields of specialty as part of a national program of further training, others prefer to meet regional further training needs. In most cases these goals are united.

Further education in the universities consists of further vocational education courses and programs, employment training, and open university instruction. Also included are rapidly expanding entrepreneurial services that are organized mainly on a ragionel-political basis. Further education centers in university communities and their 